\title{
LEVELS OF SECURITY AND POSTMODERN SOCIETY
}

\author{
Svilen Stefanov ${ }^{1}$, Venelin Terziev ${ }^{2}$, Vanya Banabakova ${ }^{3}$ \\ ${ }^{1}$ Prof, Ph.D., National Military University, Veliko Tarnovo, Bulgaria, sestefanov@abv.bg \\ ${ }^{2}$ Corresponding Member of the Russian Academy of Natural History, Moscow, Russia, Prof. \\ D.Sc. (Ec.), D.Sc. (National Security), D.Sc. (Social Activities), Ph.D., National Military University, \\ Veliko Tarnovo, Bulgaria; University of Rousse, Rousse, Bulgaria, terziev@skmat.com \\ ${ }^{3}$ Prof. Ph.D., National Military University, Veliko Tarnovo, Bulgaria, email: v.banabakova@abv.bg
}

\begin{abstract}
The rapid development of science and technology has led to the emergence of a crisis in society. Science „pushes"religion, but does not offer a new moral code in its place. The definitions of „security" are almost as many and as controversial as postmodernism. For the purposes of this study, however, it will be sufficient to define security as „the functional state of a system that provides for the neutralization and counteraction of external and internal factors affecting or potentially damaging the system. This scientific article presents a study, which seeks to answer the question why the paradigm "security“ is so important in the postmodern society, what are the roots of its influence and meaning, and to seek conclusions and guidelines for its increase. The main features of the postmodern society, some prerequisites and their implications, as well as their impact on the security of all its levels are examined. The subject of the study is the postmodern society with its specific features, and the subject - the security as an indissoluble element of the social relations in the contemporary world.
\end{abstract}

Keywords: security postmodern society, globalization.

\section{INTRODUCTION}

Rapid development of science and technologies leads to crisis in society growing up. Science "pushes" religion aside but does not offer new moral code in exchange. Even the opposite, the wide application of modern technologies in the times of both world wars and this mainly for making weapons for mass destruction shows that the application of scientific results without moral limitations leads to horrible consequences. The lack of "goals" and "landmarks" in the moral base of public consciousness creates preconditions for the loss of value system, practically, in several generations. Unfortunately, this process has not finished even today.

The term „postmodernism“ means what comes after the modernism. As some researchers say, the prefix "post“ is very suitable because it shows that postmodernism originates directly from modernism and the transition between both has rather evolutionary than revolutionary nature. The term "postmodernism" (2017a) is used for the first time yet in 1917 in the works of Rudolf Pannwitz, German writer and philosopher- 
essayist. Later the term is used by number of authors with various meanings, but mainly for presenting modern experimental streams in art, which do not follow the ideas of "modernism“, mainly of abstract art. Actually, most often, returning to realism and creation of works (artistic, literature, etc.) accessible for understanding by the masses is most often understood in art behind the term „postmodernism“ or in other words - denial of modernism. The term gains real popularity with the publishing of the book "The Language of Postmodern Architecture" by the American architect Charles Jencks in 1977. Consequently the meaning of the term „postmodernism“ extends and embraces philosophy, sociology and practically, all fields of modern science and art. This happens with the emergence of a stream in the French philosophy (Althusser, Derrida, Lyotard, etc.). Actually, to date there are many in number definitions of "postmodernism" that are used and established by various schools in science and art, and great part of them are completely mutually exclusive. Here are few examples:

Jurgen Habermas, Daniel Bell and Zygmunt Bauman define postmodernism as result of politics and ideology of neoconservatism, characterized by aesthetic eclecticism, turning objects for consumption into fetishes and other specific features of postindustrial society;

Umberto Eco interprets postmodernism in a broad sense, as mechanism for change of one cultural period with another;

Hassan, Welch, Lyotard consider that postmodernism is a common cultural denominator of the second half of the 20th century, unique period, where the world is reviewed as chaos;

According to Letten and Suleiman postmodernism does not exist, it could be reviewed as giving a new meaning to the cultural postulates of modernism, but the independent postmodern reaction is a myth;

Küng and Tarnas - postmodernism is a period that comes to change the European „New Age“. The latter is characterized by infinite trust in the power of mind and progress. The crash of the value system has happened during the First World War. As a result, the Euro-centric paradigm is exchanged for a global polycentrism, and the infinite trust in mind gives up its place to the „interpreting thinking“.

Naturally, there are number of critics towards the thesis of postmodern society. Most of them are directed to the statement that postmodernism does not exist and this is rather late modernism (Chomsky, Dennett, Solzhenitsyn, etc.).

It is obvious that modern world is not the same as it was during the first half of the 20the century. Public, social and economic relations undergo changes, transform in new and different things, which most of the time are unknown from the history of humankind. This shows we really are in a new period. Whether we'd call it postmodernism or another way is not an essential issue in this case. It is more important to know its characteristics and to be prepared for the coming changes. All authors, who develop the thesis about postmodernism and the society in this period, unite around one idea. The chaos in public, social, political and economic relations, the crash of the old value systems and the lack of new ones to exchange them are features showing that actually this is a transitional period, transitional process while the society (as a system) transfers form one status to another. Unfortunately, the new status and the new relations are not outlined yet and practically cannot be defined and clearly pointed. Historical references point that these transitional periods are characterized by long continuance and very often by impetuous social events, wars and bloodshed.

Logically, as extension of the reasoning above, the term „security” comes. And here, almost all authors examining postmodernism are unanimous about security being one of the leading paradigms of modern society. Its significance grows exponentially I would say, during the last years and this reviewed mainly from practical point of view rather than in theoretical respect.

The definitions of the term „security” are almost as many and controversial as the ones of postmodernism. But it would be sufficient, for the goals of the present study, to define security as "given system's functional status that ensures its neutralization and counteraction to external and internal factors, which influence or able to impose destructive influence upon the system" (2017b).

The goal of the present study is to look for an answer to the question why the paradigm "security" is so important in the postmodern society, what are the roots of its influence and significance and respectively, to look for conclusions and directions for its enhancement. The main characteristics of the postmodern society, some preconditions and their consequences as well as their impact upon security at all its levels would be reviewed.

The study's subject is the postmodern society with its specific features and its object - the security as an inseverable element of social relations in the modern world. 


\section{SECURITY}

Prof. Slatinski (Slatinski, 2010a) develops the thesis that in order security to be reviewed in more detail, in order it to be more understandable, it is advisable for it not to be reviewed as unified generalized term, but to be split into elements according its main subjects. He suggests five levels of security, as follows: Security of the Individual; Security of the Group of individuals; Security of State; Security of the Community of states; Security of the World.

There are also other suggestions for splitting the levels of security, but actually they overlap in different extent the decomposition suggested by Slatinski. As he emphasizes, "although split from first to fifth, these levels should not be accepted as more or less important. Each one of them has its specific meaning. Of course, the nature of the relevant society should be considered and especially the modern trends, goals and priorities in providing the security".

A definition of the term „Security” was pointed in the introduction of the present study, which was accepted for basic and all following reasonings would be grounded on it.

We would review in short the separate levels, considering they are defined and described in details by other authors, and also considering their connections with the postmodern society characteristics. In order to avoid repeated quoting of the same source, I am noting that the basic concepts for each of the levels are taken from (Slatinski, 2010a).

\subsection{The Security of the Individual}

According to Daniel Deudney "human security“ is like the concept for "sustainable development" everybody is "for", but few understand what it means. It is so because its existing definitions are far too general, unclearly outlined and embracing everything. The concept for human security is developed in details for the first time in 1994 in the UN Human Development Report. According to it, the most important components of this level of security, are: economic security (lack of threat of poverty); food security (access to food); health certainty (access to healthcare and protection from diseases); ecological security (protection from dangerous pollution and exhaustion of environment); personal security (protection from torture, wars, criminal assaults, domestic violence, drug abuse, suicides and even traffic accidents); community security (survival of traditional cultural and ethnic groups, physical security of these groups); political security (respect toward the civil and political rights).

Number of authors and organizations suggest their definitions for the scope of the studied term but because of the limited size of the present paper they will not be reviewed as far as, to a certain extent, they overlap or embrace separate elements of the ones listed above.

In the developed countries, mainly from the Euro-Atlantic community, individual security, individual prosperity and individual well-being have leading accent not only in the country's governing but also within the spectrum of goals and values of individuals. This means that a key element in evaluating the activity and competence of each governing structure, at any level nationwide is how it guarantees an acceptable level of individual (personal) security, for as many as possible citizens.

It is important to take notice that it is sai "for as many as possible citizens", and not the generalized "all citizens". Between the two terms, there is not a small multitude of citizens, for whom the "acceptable" level of personal security obviously would not be ensured. For them the country will "look like" neither wealthy, nor secure. Moreover, as big the multitude is, as more distributed the feeling of insecurity in people would be. Actually, the great number of people for whom the rule for ensuring personal security on the behalf is not in power, and the daily meetings of the rest (privileged) citizens reduce the feeling for security of the latter, too. It might be said this is one of the reasons for strengthening the feeling of insecurity at personal level, especially in the not so developed countries.

Zygmunt Bauman studies another reason for loss of individual's feeling of security in (Bauman, 2003b). He draws security, the feeling of security, as key characteristics of the pre-modern community and limits it historically with the coming of modernity, when freedom turns into the epoch's principle. Security and freedom are the two poles of human social life. The desire of a human to acquire more freedom, to gain more territories for the autonomous human wills is in the base of this historical transition, which we call modernity. But he perforce rejects the type of security the pre-modern community enjoyed, which allowed the stable joint self-realization in a situation of small risk. Freedom is fundamental value but is connected with risk; risk kills security; the community disintegrates from there. More, the community makes the others inevitable part of our inner world, while in the modern and especially late-modern society the others are not obligatory, they do not construct our free individuality, even often, namely they produce insecurity and, 
hence, they are threat for this individuality. And, in order the issue to get more complicated, Bauman adds that returning back to the status of security, returning back to community is already impossible. According to him, freedom has been only a temporary consequence of the pre-modern communal order's collapse; it has been soon substituted by the authority of modern elites, by the universal supervision. And the postmodern disintegration we witness today just marks the end of the endless efforts of modernity to construct new type of communities in the name of security. The postmodern disintegration in the long run, deprives the modern labyrinth idea of all its sense because premises the lack of end, of one definite and fixed goal. It seems that the goal is chosen individually and is consumed individually. The criteria, Bauman says, is not aesthetic and individual to a certain degree but aesthetic according to what we like. The individual reality does not exist and that is why our nostalgy for the community could be satisfied by the participation in a community of nonbelonging, in togetherness of recluses.

\subsection{Security of the Group of Individuals}

In order a group of people to be a Group according to the theory of security, it is necessary for a number of conditions to be satisfied, which generally include: the individual of the group to have common needs, necessities and desires, which to be satisfied, as well as common threats, dangers and fears, which have to be answered. In other words, the group should differentiate and self-identify as a community with inherent characteristics of a complex adaptive system.

As a rule, the Group has in it basic material and spiritual values, culture, identity, memory, language, traditions and customs. Their preservation and respecting are important aspects of its security. The group is very sensitive to these identification markers, through which it outlines its borders from other groups and the society as a whole. Very often the representatives of such groups consider these values of theirs are infringed from outside - by the majority, by the society or by other groups. In this sense, it is spoken about peculiar complex of vulnerability of the Group.

Four basic functions, suggested by Talcott Parsons, known as AGIL, are typical for each group. They are:

(A) Adaptation - adapting to the constantly changing environment;

(G) Goal attainment - these are the goals that the group or its members like to achieve, which leads to Group's behavior change outside the frame of simple models and adaptation;

(I) Integration - this includes uniting of the members and sub-groups in the Group, efforts for the various activities to be made and maintained compatible, arousing and maintenance of people's motivation being compatible with their imposed roles;

(L) Latent pattern maintenance - these essence models (patterns) have to be reproduced constantly in order to be preserved.

Two additional basic functions are added for the more developed systems:

- Goals setting - the more complicated systems have the ability to choose and create quality new goals, i.e. to define strategies for development;

- Capability for training - this is connected with the process of change of Group's behavior under the pressure of outside circumstances, i.e. it "trains" for survival, adaptation, achieving new goals or for enhancing its effectivity and affectiveness.

The Group could organize according to various indications - eyhnic, religious, territorial, social, professional as well as some other specific criteria like sexual orientation, specific capabilities (for example, disabilities), etc.

The security of the Group keeps its important significance, despite the feeling that the world gradually turns into multitude of individuals that are automized and following personal interests. The division (atomization) takes many of the moral responsibilities and moral inhibitions off the separate individual. This leads to increasing the meaning of own Ego, which attains primary importance for these people. If part of the society succeeds in taking advantage of that freedom, not a few people realize that modern freedom puts personality in a status of isolation and impotence. Stable trends for escape from such type of freedom, which other name is insecurity, arise.

One of the most pressing needs of a person, not weaker than the physiological needs, is the need to connect to the outside world, the need of escaping loneliness. The feeling of loneliness and isolation leads to psychological degradation the same way physical hunger leads to death. Religion, nationalism, various customs and beliefs, no matter how absurd and destructive are, if they connect the personality with other people, they are salvation from the greatest horror for the human - isolation. 
Preserving identity is of a particular significance for the groups of individuals, and it and its preservation are directly connected with the term, introduced by the so called "Copenhagen school", "societal security“. According to Barry Buzan and Ole Wæver there is societal security, when the communities of people review given status or development as threat for their existence as community.

Other researchers analyze the differences between national and societal security:

National security includes protection of the independence, sovereignty and territory of the state from military attacks and political domination of another state, i.e. it is concentrated on the political control and is connected mainly with sovereignty.

Societal security is mainly connected with the ability of a society to preserve its natural character in changeable conditions and at possible and real threats. In other words, societal security is connected with sustainability within acceptable conditions for evolution of the traditional models of language, culture, associating, religious and national identity and customs. It mainly regards the identity, the ability of a certain nation to maintain its culture, its institutions and its way of life.

\subsection{Security of the State}

As it was mentioned above, the security of the State is connected with protection of the fundamental values: territorial integrity, sovereignty, independence, constitutional and interior order, etc. Scientists, philosophers and military experts since deep antiquity have emphasized that the main among all the reasons for a State coming into being is the need to guarantee the security (defence and public order) of society. It is a completely natural process that the State's originating is result of the society's and separate individual's striving for more security.

The relation State - Security is complex, non-linear and no reverse connections exist in it. Between both, there is constant process of interaction, mutual penetration, mutual consolidation or relevantly - exhaustion. It has been considered in the course of centuries that stronger State means more Security and in most cases, it was this way. The relation between both terms loses its linearity with the multiplication of the possible and direct threats and upon certain circumstances, it even turns being the contrary, namely stronger State means less Security. This is due to the fact that since a particular historical period onward, within the State, Security started being competed by other welfare and values - Freedom, Human rights and before all, Democracy.

Democracy takes the priority of Security among the values and welfare offered by the State. Society does not agree any more to stay obediently and passively in the cage of Security, and this is in fully in force for the separate individual, too. Full-value democracy separates the security of society and the governed ones from the security of political elite and the governing ones.

Democracy's priority is the security of society and the governed ones. Political elite's security cannot be state's end in itself; it is consequence of its normal functioning. Otherwise, force structures, as state bodies, are burdened with unusual functions for regime's preservation.

The terms State's security and the security of the governing elite fuse completely in the non-democratic countries, and the security of the individual and the various communities is offered as sacrifice to them. Through violence, manipulations, propaganda and finding enemies - interior and exterior, the society in the non-democratic countries is made to identify its security with the one of the regime or at least to start living with the notion they have the same priority. This way the state destroys the security of its society.

The State has various procedures, mechanisms and tools for guaranteeing security. It is the only legitimate body that can exercise power. Still, number of tasks, functions and powers regarding security guaranteeing are monopoly of the state.

However, there are clearly outlined trends and standpoints that the State should limit many of its security functions and to "privatize” them. Particularly the representatives of modern liberalism consider that the government's power has to be limited. It has irrevocable functions such as maintenance of military power and interior order, construction of infrastructure and encouraging education, but on the other hand it has to ensure free market economy and not to conduct actions that hinder its natural course. However, in case Security is an essential element of State, then drawing out of this role makes its existence practically useless.

State's role minimization is connected with one more hidden from the society change that political elites gradually conduct without giving the societies the possibility to rationalize and to assess to what an extent it is in interest of them. The word goes about the substitution of "welfare" with "services". Welfare distribution is connected with the principle of "unconditionality", i.e. everybody gets fairly his share of them. Services 
distribution, anyway, is realized according to the criterion „solvency“, i.e. everybody gets as much as he is able to pay for. Health, education, security are all social welfare, gradually turned into services.

One of the most update topic in the international debate about the role and place of State regarding security is connected with the evolution of the Classic Security State and its institutional support. They are four and include the army, the police, the Special Forces and the defense industry.

One of the leading trends in international security is the growing role of natural, anthropogenic and technogenic calamities, averages and catastrophes and the necessity of more and more resources for their early announcing, prevention, in-time reaction, counteraction and liquidating the consequences. As a result of these processes, the four supports of the classic security State confront a powerful competitor for resources, namely Civil protection or Civil security.

Two approaches are possible here for solving the arising problems and conflicts. The first one supposes the construction of a new - fifth support of state security in the person of the mentioned civil protection, with the corresponding institutions, procedures, possibilities and tools. The second is made of developing the four classic supports in a way that allows each of them to take part of the obligations and responsibilities of civil security. If it does not make it, then the relevant support risks losing part of the sense of existing and correspondingly - of the society's support.

\subsection{Security of the Community of States}

Similar to the group of individuals, the Community of states should correspond to certain conditions in order to be subject to be studied by the theory of security. These conditions might be summarized in the following: some extent of interior cohesion, consolidation and integrity should exist among the countries, originating from the existence of common values, interests or goals or from the presence of common threats, dangers and fears, which should be answered. The indications possible for establishing or forming communities of countries are many and we will not review them in details here.

According to the American scientist Karl Deutsch, successful integration requires feeling for community that includes mutual sympathy, respect, trust and loyalty among the integrating parties, at least partial community in the terms, perceptions and interests, two-way successful possibility for foreseeing the behaviour, joint actions in accordance with that behaviour. Shortly, building the community is a continuous, dynamic process of shared attention, communication, understanding of needs and responsiveness in developing and taking decisions.

Kar, Deutsch reviews two types of security communities:

- Amalgamated communities - they are built through formal uniting of two or more previously independent units into one integral, bigger entity, with a kind of joint government;

- Pluralistic security communities - the ones that are much easier achievable and to some extent sufficient if the main goal of integration is peace. These communities are built and maintained easier because the component states preserve their independence and political autonomy, and their governments preserve their juridical independence. Hence, they are a preferred tool for preserving the peace among the component units.

There are other classifications of state security communities, suggested by various researchers around the world, but they are outside the scope of the present study.

Barry Buzan, Ole Wæver and Jaap de Wilde introduce the term „security complex“, which is a regionally based, locally grouped cluster of states, which main comprehensions and worries about security are so closely connected that the problems for the national security of each one of these states cannot be logically analyzed and solved separately from the problems of the rest. The introduction of this object in the system for the study of security gives the possibility for comparative analysis and studies of individual regions.

The classic "security complex" is defined in the light of mainly the political and military problems of security and has the following characteristics:

- It consists of two or more states;

- These states are geographically coherent grouping;

- The relations between them are defined by mutual dependence in the sphere of security, which might be positive or negative but is considerably stronger between them than them and the states outside the complex; 
- The mutual dependencies structure may be deep and long although not obligatory permanent.

The agreements for cooperative security are institutionalized or not institutionalized formations of states, formed around the security communities. They are mutually dependent on each other through cooperation in the field of security and defence, developed within the frame of a cooperative security agreement. The partners in this type of agreement do not have the same guarantees for their security as the member-states of the security communities. Common values' sharing is not a first-rate requirement for the cooperative partners but as far as they want peace and stability in the zone, they use the collective security measures. The fact that cooperative security agreements are much alike military unions comes from here.

The main characteristics of this type of agreements are as following:

- Oriented towards solving problems, not towards protection from a particular aggressor;

- Common convictions are more important that common norms, and the common norms are more important that the common identity;

- They grow up around the security communities.

The completed review of various sources shows that this field of the security science is developing impetuously now. This is definitely consequence of the fact, as it was mentioned in the previous item, that the national state, no matter how big and strong is, cannot manage with the global problems itself.

\section{Security of the World}

The fifth level of security is "Security of the World“, security of the planet, i.e. common, comprehensive, global, universal security.

The common security concept is elaborated for the first time in 1982 in the "Common Security" Report of the UN Independent Commission on Disarmament and Security Issues. According to it, lasting security cannot exist if it is not shared by all and the common security may be achieved only by cooperation based on the principles of equality, justice and reciprocity.

The main challenges before global security are defined in the analysis "Global Responses to Global Threats", developed by the Oxford Research Group (ORG):

- Climate changes and global warming;

- The competition over the more and more limited strategic resources;

- The growing social-economic division and the marginalization of the majority of people;

- Enhanced distribution of weapons and military technologies, including weapons for mass destruction (global militarization)

ORG speaks about the current orthodox agenda of security. This tendency towards previous and classic problems is defect and does not allow the political elites to direct their efforts and resources to finding sustainable, realistic and pragmatic solutions for non-traditional risks that threaten the world. This approach responds to global threats through force and fight with the symptoms - repressions against the disagreeing and maintaining the status quo. In a long term, this policy is doomed to failure. If urgent actions are not taken in the forthcoming 5-10 years, it would be difficult to avoid global calamities and global system's destabilization. They suggest to pass to "sustainable security paradigm“, a preventive approach, which attacks the roots of the problems. It suggests passing from directing the resources and energy "against war" to re-directing the resources and energy to more „peace and security" as well as from "security for some“ towards „security for all“.

In his monography (Slatinski, 2004a) „National security - aspects, analyses, alternatives“, Professor Nikolay Slatinski suggests a list of trends within the frame of the security global system. I would afford myself only to list them here without going into details as far as they are described in details in the pointed source as well as most of them are reviewed above in the present study. These trands are: (1) Deepening of the civilization contradictions North - South (i.e. between the rich and the poor countries) and West - East (i.e. between the democratic and non-democratic countries); (2) Going on of mutually connected, mutually influencing, interweaven processes of regionalization and globalization; (3) Going on of mutually connected, mutually influencing, inter-weaven processes of disintegration and integration; (4) Serious weakening of the national state's positions; (5) One-pole geopolitical model establishment; (6) Over-liberal geoeconomic model establishment; (7) Grwoing role of natural, anthropogenic and technogenic calamities, averages and catastrophes and the necessity of more and more resources for warning of them, for prevention, timely reaction and consequences liquidation; (8) Certain moving of the big countries'focus towards Asia and 
Balkans withdrawing towards the periphery of big politics; (9) Strategic value and civilization drift of the USA and Europe in different directions - „extension of the Atlantic ocean“; (10) International relations' returning to the force methods for disputes' overcoming, for crisis management and conflicts' solution, for preserving the global status quo, for control, manipulation and suppression of the disagreeing to that staus quo; (11) Growing ambition for way more significant global role of the three 1-billion's, of the Islamic world before all, but also of China, and recently of India, too; (12) Growing of the organized crime and terrorism influence and threat of them turning into geopolitical factor; (13) Developing of demographic trends that gradually change the ethnic, religious and race balance on a global scale; (14) Change in the international politics with the entering of modern and over-technological communications, when everything that happens and should be reacted to, would be in an on-line mode.

The world is in a key period of its evolution, when what way it would undertake is decided: along comparatively stable way of sustainable development, where, even if there are risks and challenges, they would be manageable and under control to a certain extent, or along much more risky scenarios and would got from one crisis through another towards third one, where governing and control would be almost conditional (Slatinski, 2014a; 2017c; 2017d; 2017e; 2017f; Bauman, 2003a; Liotar, 1996a; McCrindle, 2009a).

\section{CONCLUSION}

Postmodern society possesses all characteristics of a transitional period, typical for the complex systems at their transition from one status to another. Historical information shows that such processes are characterized by long duration and as far as at the moment we are at its very beginning, the main characteristics of the coming new cannot outline. It is, anyway, obvious that not only technologies change, but also society's entire structure as well as the people's way of thinking, especially the ones' of the new generations. This logically and naturally leads to the feeling for "security" decreasing in each separate individual as well as in communities, and in the society as a whole. This way the scientific community's interest towards this paradigm study grows, and also does the interest of "ordinary people" as far as these studies' practical aspects concern they daily life and existence.

More and more world cannot be viewed as just multitude od states and regions that exist each for itself. Global problems require global solutions. This pushes researchers to pay way more attention to the largedimensions 'levels of security - „The Security of a Community of States" and "World Security". There are really gaps in this direction and also possibilities for studies and analyses.

\section{REFERENCE LIST}

https://ru.wikipedia.org/wiki/\%D0\%9F\%D0\%BE\%D1\%81\%D1\%82\%D0\%BC\%D0\%BE\%D0\%B4\%D0\%B5\%D 1\%80\%D0\%BD\%D0\%B8\%D0\%B7\%D0\%BC, 03.06.2017, (2017a).

https://bg.wikipedia.org/wiki/\%D0\%A1\%D0\%B8\%D0\%B3\%D1\%83\%D1\%80\%D0\%BD\%D0\%BE\%D1\%81\% D1\%82, 03.06.2017, (2017b).

Slatinski, N. (2014a). Sigurnostta - zhivotat na mrezhata, Voenno izdatelstvo, Sofiya, 2014 (Слатински, Н. Сигурността - животът на мрежата, Военно издателство, София, 2014).

http://www.librev.com/index.php/prospects-world-publisher/77-2009-06-17-08-28-18, 05.06.2017, (2017c).

https://bg.wikipedia.org/wiki/\%D0\%93\%D0\%BB\%D0\%BE\%D0\%B1\%D0\%B0\%D0\%BB\%D0\%B8\%D0\%B7\% D0\%B0\%D1\%86\%D0\%B8\%D1\%8F, 05.06.2017, (2017d).

https://bg.wikipedia.org/wiki/\%D0\%9B\%D0\%B5\%D0\%B3\%D0\%B8\%D1\%82\%D0\%B8\%D0\%BC\%D0\%BD\% D0\%BE\%D1\%81\%D1\%82, 05.06.2017, (2017e).

https://ru.wikipedia.org/wiki/\%D0\%A0\%D0\%B5\%D0\%B2\%D0\%BE\%D0\%BB\%D1\%8E\%D1\%86\%D0\%B8\%D $1 \% 8 \mathrm{~F}, 06.06 .2017,(2017 f)$.

Bauman, Z., (2003a). City of Fears, City of Hopes. London: Goldsmith's College, 2003.

Liotar, Zh. (1996a). Postmodernata situatsiya. Izlozhenie za sastoyanieto na savremennoto znanie, Sofiya, Nauka i izkustvo,1996 (Лиотар Ж., Постмодерната ситуация. Изложение за състоянието на съвременното знание, София, Наука и изкуство,1996). 
Bauman, Z. (2003b). Obshtnostta - tarsene na bezopasnost v nesigurniya svyat, LIK, 2003 (Бауман, 3. Общността - търсене на безопасност в несигурния свят, ЛИК, 2003).

McCrindle, M. (2009a). The ABC of XYZ: Understanding the Global Generations, University of New South Wales, Sidney, 2009.

Slatinski, N. (2010a). Pette niva na sigurnost, Sofiya, Voenno izdatelstvo, 2010 (Слатински, Н. Петте нива на сигурност, София, Военно издателство, 2010).

Slatinski, N. (2004a). Natsionalnata sigurnost - Aspekti, Analizi, Alternativi, S. Balgarska knizhnitsa, 2004 (Слатински Н., Националната сигурност - Аспекти, Анализи, Алтернативи, С. Българска книжница, 2004). 